\title{
Studi Budaya Pasar Tradisional dan Perubahan Gaya Hidup Masyarakat Pedesaan: Kasus Pasa Nagari dan Masyarakat Nagari di Propinsi Sumatera Barat ${ }^{1}$
}

\author{
Nursyirwan Effendi ${ }^{2}$
}

\begin{abstract}
This paper about study culture traditional markets in the context of rural communities who is going through the changing lifestyle. The changing lifestyle modern society are familiar caused by one of them by the development of consumerism provided by modern markets. But, the changing lifestyle is also held in rural communities who also through the market .Traditional markets which were held because mechanism social and cultural and becoming the place of transactions local economy product and needs of society village, they have moved on as a place for products modern and lifestyle modern .How the peoples lifestyle caused by traditional markets ? What shape culture traditional markets after the peoples lifestyle changes to the form from which modern ? This paper according to the about a analysis culture market focus on reconstruction pranata traditional markets held in rural communities in west Sumatra. Unit analysis is pasa nagari. The assumption anthropology about the marketplace traditional is a pranata that are integral of social systems culture of the communities of which market are located and lasting.A method of qualitative research used to analyze existence culture traditional markets.The research is a number of markets nagari and the community nagari in the district of flat land and kabupaten agam, west sumatra.Research results related to ( 1 ) review of comprehensive about existence traditional markets the weakening, in the center of strong penetration lifestyle modern markets, by taking cases the community nagari in west sumatra; ( 2 ) factors cultural the center of local people who have weakened or strengthen the existence of culture market tradisional.produk this expected to be used as a reference the blue print ) to varying the efforts to build, develops and maintain culture traditional markets in indonesia.
\end{abstract}

Keywords: Market Culture, Traditional Market, Pasa Nagari, Life Style, Consumerism, Modern.

\begin{abstract}
Abstrak
Makalah ini tentang kajian budaya pasar tradisional dalam konteks masyarakat pedesaan yang sedang mengalami perubahan gaya hidup. Perubahan gaya hidup masyarakat modern sudah terbiasa diakibatkan salah satunya oleh perkembangan konsumerisme yang disediakan oleh pasar-pasar modern. Namun, perubahan gaya hidup ternyata juga berlangsung di masyarakat pedesaan yang juga melalui pasar. Pasar tradisional yang semula berlangsung karena mekanisme sosial dan budaya dan menjadi tempat transaksi produk ekonomi lokal dan kebutuhan masyarakat desa, telah bergeser sebagai tempat bagi produk modern dan gaya hidup modern. Bagaimana perubahan gaya hidup masyarakat yang disebabkan oleh pasar tradisional? Apa bentuk budaya pasar tradisional setelah berlangsungnya perubahan gaya hidup masyarakat ke bentuk yang modern? Makalah ini berdasarkan riset tentang suatu analisis budaya pasar yang memfokuskan kepada rekonstruksi pranata
\end{abstract}

\footnotetext{
${ }^{1}$ Makalah disajikan pada acara Seminar Nasional ke I FISIP Universitas Andalas"Peran Ilmu-Ilmu Sosial dalam Pembangunan Indonesia Baru"15-17 Oktober 2014 di Padang

${ }^{2}$ Penulis adalah Guru Besar Jurusan Antropologi FISIP Universitas Andalas
} 
pasar tradisional yang berlangsung di masyarakat pedesaan di Sumatera Barat. Unit analisis adalah pasa nagari. Asumsi antropologi tentang pasar tradisional adalah suatu pranata yang integral dari sistem sosial budaya dari masyarakat dimana pasar tersebut berada dan berlangsung. Metode riset kualitatif dimanfaatkan untuk menganalisis eksistensi budaya pasar tradisional. Lokasi riset adalah sejumlah pasar nagari dan masyarakat nagari di wilayah kabupaten Tanah datar dan Kabupaten Agam, Sumatera Barat. Hasil yang riset menyangkut (1) telaah komprehensif tentang eksistensi pasar tradisional yang semakin melemah, ditengah kuatnya penetrasi gaya hidup pasar modern, dengan mengambil kasus masyarakat nagari di Sumatera Barat; (2) faktor-faktor budaya yang utama dari masyarakat lokal yang telah memperlemah atau memperkuat keberadaan budaya pasar tradisional.Produk ini diharapkan dapat dipakai sebagai rujukan utama (blue print) untuk berbagai upaya membangun, membina dan mempertahankan budaya pasar tradisional di Indonesia.

Kata-kata Kunci: budaya pasar, pasar tradisional, pasa nagari, Gaya hidup, konsumerisme, modern

A. Pendahuluan

$\mathrm{K}$ eberadaan budaya pasar tradisional di masyarakat Indonesia semakin terancam baik dari sisi fisik/tempat keberadaannya maupun budaya yang mendasarinya. Ancaman yang paling utama adalah perkembangan budaya pasar modern yang secra lambat namun pasti masuk dalam masyarakat pedesaan. Proses perkembangan pasar modern di Indonesia berikut budayanya berlangsung melalui arus perjalanan komoditi produk modern yang tidak diproduksi lokal, namun diproduksi oleh negara produsen dari luar seperti Tiongkok, Malaysia, Thailand, Amerika, Jerman dll. Komoditi yang masuk sangat beragam klasifikasinya, seperti klasifikasi alat-alat rumah tangga, makanan, bahan baku perumahan, pakaian dan tekstil, alat perkantoran, kendaraan bermotor, dan otomotif lainnya. Keberadaan komoditi modern menjadi pintu masuk bagi perubahan perilaku dan pola pikir masyarakat. Secara keseluruhan, peruba han tersebut akan memunculkan berbagai gaya hidup yang berbeda dari sebelumnya.

Dalam konteks Indonesia, mulai dari Aceh sampai dengan Papua, pasar tradisional biasanya eksis di dalam lingkup masyarakat lokal/pedesaan, sehingga penggambaran gaya hidup dan budaya pasar tradisional sering identik dengan karakter sosial budaya masyarakat lokal/ pedesaan. Meskipun suatu pasar terletak di dalam kota namun masih memiliki karakter sosial lokal, maka pasar tersebut sering disebut sebagai budaya pasar tradisional. Salah satu identitas budaya pasar tradisional adalah dari penamaan sesuai lokasi wilayah keberadaanya, seperti pasar Angso Duo, pasar Talang Banjar Duo di Jambi, Pasar 16 llir dan pasar Cinde di Palembang, pasar Apung di Banjarmasin, pasar Pajak sore Padang Bulan dan Pasar Baru Belakang di Medan, Pasar Atas di Bukittinggi, Pasar Batu Akik Rawa Bening, Jakarta, Pasar Beringharjo, Yogyakarta, Pasar Jati Ngaleh di Semarang, Pasar Klewer di Solo, istilah pasar Pasar Lama dan Pasar Keget Batu Meja di Ambon, Pasar Pinasungkulan di Manado Pasar Wosi, di Manokwari, dsb. Pasar-pasar tersebut tergolong sebagai pasar tradisional yang digambarkan erat kaitannya dengan tipe gaya hidup masyarakat lokal. Sejalan dengan perkembangan budaya pasar modern, maka eksistensi budaya pasar tradisional dalam suatu masyarakat sedang mengalami ancaman perubahan. Secara antropologis, pasar tradisional merupakan salah satu representasi dari pranata budaya ekonomi lokal. Dengan demikian, terancam nya keberadaan budaya pasar tradisional turut mempengaruhi keberadaan kebuda yaan suatu masyarakat. Konsep yang dipakai untuk menempatkan pasar dalam kebudayaan suatu masyarakat adalah budaya pasar (market culture) (Hefner, 1998). Dalam pengertian ini, Hefner (1998) menguatkan argumen bahwa suatu budaya pasar adalah keterkaitan dalam kondisi sosial dan bangun moral yang menaungi nya.

Pemaknaan budaya pasar berakar dari definisi kebudayaan menurut Koentja raningrat (1996:74-82) bahwa kebudayaan 
memiliki empat wujud, yakni artifacts/bendabenda fisik; sistem tingkah laku dan tindakan yang berpola; sistem gagasan; dan seperangkat nilai. Berdasarkan hal tersebut, maka budaya pasar dipahami dalam empat wujud yaitu (1) eksistensi fisik tempat dimana suatu pasar tradisional berlangsung, seperti lahan, tipe bangunan dll.; (2) seperangkat aktivitas (baik ekonomi mau pun sosial) yang berpola dan kontinyu dari berbagai pelaku pasar beserta variasi peran dan fungsi mereka, seperti jual beli dengan cara tawar menawar, bercengkrama/ (socializing), sifat sosialnya berpola paguyuban, dll. (3) Sistem gagasan yang melatarbelakangi berlangsungnya eksistensi fisik dan seperangkat aktivitas para pelaku pasar untuk menjalankan peran dan fungsi mereka, seperti gagasan pasar sebagai arena sosial, gagasan pasar sebagai mencari nafkah, gagasan cara berjualan, gagasan menentukan keuntungan jual beli, dll; (4) nilai yang menjadi dasar bagi sistem penyelenggaraan budaya pasar tradisional, seperti nilai solidaritas, nilai pertemanan usaha, nilai keakraban, dll.

Secara faktual, terdapat perkemba ngan yang kontras antara budaya pasar tradisional dan budaya pasar modern. Kontradiksi dari kedua budaya pasar ini terletak kepada variabel perilaku, khususnya, gaya hidup masyarakat yang terintegrasi dalam eksistensi pasar lokal mereka. Secara fisik, pasar-pasar tradisional di Indonesia mengalami tekanan akibat pertumbuhan pasar modern dan ekspansi ritel modern (Ditjen NBSF, 2005; Kompas/ 15/3/2010). Pertumbuhan ini cenderung terus meningkat dari tahun ke tahun sebesar $31,4 \%$, atau dalam rentang tahun 2003-2008 mencapai pertumbuhan sebesar $162 \%$. Sementara perkembangan pasar tradisional mengalami stagnasi ataupun kalau mengalami penurunan telah mencapai sekitar $8 \%$ per tahun (Ditjen NBSF, 2005: 5, Kompas 15/3/2010). Kontradiksi wajah kedua tipe pasar ini juga ini sangat nyata. Pasar tradisonal sering tak terurus dan selalu diidentikkan dengan ciriciri kondisi fisiknya yang sederhana, umumnya bangunan pasar tidak permanen, struktur ruang yang centang perenang. Lingkungannya kurang nyaman karena selalu terlihat becek, sempit, gelap, kotor, bau, sumpek dan suasana sosial dianggap akrab. Sebaliknya pasar modern digambarkan sangat kontras, yakni sebagai suatu lokasi/sarana jual beli yang berada dalam bangunan megah, permanen, nyaman, luas dan aman, serta ruang terstruktur dengan rapi.

Akibat pertumbuhan sejumlah besar bentuk fisik pasar modern yang semakin gencar, pasar-pasar tradisional terkena dampak yang cukup parah. Sejumlah dampak tersebut di antaranya menurunnya omzet perdagangan para pelaku pasar tradisional, menurunnya peran pasar tradisional sebagai "tuan rumah" bagi komoditi lokal yang diproduksi oleh masyarakat setempat, beralihnya tradisi masyarakat dalam berjual beli dari pasar tradisional ke pasar modern, tergusurnya/ tutupnya pasar tradisional dan digantikan dengan bangunan pasar modern, seperti supermarket, mall dsb. Akibat non fisik dari perkembangan pasar modern adalah terbentuknya gaya hidup masyarakat yang mementingkan imej, simbol dan identitas yang dibentuk oleh komoditas atau kepemilikan barang-barang konsumtif yang dijual dalam pasar modern.

Pasar tradisional sangat penting keberadaan dan fungsinya bagi masyarakat lokal, atau pedesaan, di Indonesia. Secara kultural, beberapa wujud kehidupan masyarakat diberikan oleh pasar tradisional (1) sebagai pusat perilaku ekonomi yang diwarnai oleh karakter sosial masyarakat lokal, (2) sebagai orientasi sosial di tengah masyarakat. Dengan demikian, semakin tertekannya, atau terpinggirkannya pasar tradisional maka akan berpotensi mengikis posisi eksistensi perilaku dan orientasi sosial masyarakat.

Secara sosio-antropologis, pasar tradisional seharusnya dapat terus bertahan di tengah masyarakat, karena pasar tradisional bukan hanya wujud fisik suatu tempat berlangsungnya jual beli/ekonomi lokal, tetapi yang lebih penting lagi, pasar tradisional merupakan representasi budaya ekonomi suatu masyarakat (Geertz, 1963; Friedland dan Robertson, 1990; Evers 1994; Effendi 1999, 2005). Karenanya, pasar tradisional tidak sekedar tempat jual beli, tetapi biasanya tempat terselenggaranya sejumlah aktivitas yang sangat khas karena dilatarbelakangi oleh seperangkat nilai tertentu, dikelola menurut norma dan etika serta dilembagakan dalam suatu proses sosial (instituted process) dalam suatu 
konteks budaya (Polanyi, 1984). Dengan demikian, pasar tradisional bersuasana unik yakni sebagai karakter sosial budaya masyarakat lokal dimana pasar tersebut terselenggara.

Berdasarkan kondisi aktual bahwa, di satu sisi, di Indonesia pasar tradisional semakin bergeser posisinya karena perkembangan pasar modern, dan di sisi lain, pasar tradisional menjadi bagian yang tidak terpisahkan dari gaya hidup masyarakat lokal, maka diperlukan upaya mencari tahu eksistensi budaya pasar tradisional di tengah perkembangan budaya pasar modern tersebut melalui analisis variabel perubahan gaya hidup masyarakat pedesaan.

\section{B. Permasalahan}

$\mathrm{D}$ ari latar belakang di atas, timbul persoalan yakni: bagaimana pasar tradisional dapat bertahan dengan muatan budayanya dalam menghadapi perkembangan budaya pasar modern di pedesaan? Bagaimana gaya hidup masyarakat pedesaan memberikan kontribu si terhadap keberadaan budaya pasar tradisional?

Argumentasi dari pertanyaanpertanyaan tadi sebagai berikut. Propinsi Sumatera Barat, sebagai ranah utama kebudayaan Minangkabau, adalah salah satu wilayah di Indonesia yang memiliki tradisi/budaya pasar tradisional yang kental. Pasar-pasar tradisionalnya dikenal dengan istilah pasa atau balai, yang telah muncul sejalan dengan keberadaan kesatuan masyarakat lokal yang disebut nagari. ${ }^{3}$ Tidak disangkal bahwa dengan adanya tradisi pasa nagari, etos budaya orang Minangkabau sering diidentikkan dengan karakter

entrepreneur/wirausaha/berdagang. Sesuai namanya, pasa nagari berlangsung dalam konteks budaya lokal di suatu masyarakat nagari (sebutan desa di Sumatera Barat), sehingga aktivitas yang berlangsung di

${ }^{3}$ Dalam sejarah adat di Minangkabau, Sumatera Barat, setiap nagari, sejenis desa, diwilayah ini selalu dilengkapi dengan keberadaan pasar tradisional.Sejauh ini terdapat tidak kurang dari 560 nagari se-propinsi Sumatera Barat.Diasumsikan jumlah pasar tradisional juga hampir sebanyak jumlah nagari tersebut. (Sumatera Barat dalam Angka 2006)

108 I P a g e dalamnya, secara normatif, sesuai dengan karakter sosio-budaya masyarakat lokal tersebut.

Berdasarkan riset peneliti sebelumnya (Effendi, 2005, 2009), kekhasan pasar-pasar tradisional di Sumatera Barat, terutama pasca tahun 2000an, sudah tidak terlalu dominan berkarakter budaya lokal masyarakat nagari. Penyebab utama di Sumatera Barat adalah masuknya sentuhan budaya pasar modern yang berkembang dalam wilayah ibu kota kabupaten dan kota. Salah satu daya pengaruh besar adalah keberadaan pasar ritel mini market dan supermarket, seperti Matahari, Ramayana, Robinson, dsb. yang menggejala, yang menjadi alternatif aktivitas ekonomi masyarakat lokal untuk berbelanja pada konteks masyarakat ibu kota propinsi. Konsekuensi dari perkembangan tersebut adalah perubahan gaya hidup masyarakat yang ditimbulkan oleh tawaran berbagai produk, imej dan identitas dari pasar modern. Meskipun, secara fisik pasar modern tidak hadir menggeser pasar tradisional, namun masuknya komoditas non-lokal bahkan global ke dalam pasa-pasa nagari, ikut mempengaruhi orientasi gaya hidup masyarakat lokal kepada gaya hidup modern dan menyentuh pasar tradisional sebagai media masuknya budaya hidup baru. Faktanya, masyarakat lokal semakin konsumtif-materialis yang kemudian merembet kepada perubahan ciri sosiobudaya di lingkup pasar-pasar tradisional.

Berangkat rumusan masalah tersebut di atas, oleh karena keberadaan budaya pasar modern yang semakin memperlemah keberadaan budaya pasar tradisional, maka diperlukan upaya untuk mencari tahu keberadaan budaya pasar tradisional. Hal ini sangat penting (1) karena keberadaan pasar tradisional sama penting nya dengan mempertahankan eksistensi kebudayaan masyarakat setempat, dan (2) karena pasar tradisional sebagai salah satu aset budaya nasional Indonesia yang paling banyak memberikan warna kehidupan sosio ekonomi masyarakat lokal. Karenanya, dapat diprediksi bahwa kehilangan keberadaan budaya pasar tradisional akan berpengaruh kepada gejala ketidak harmonisan sosial. 


\section{Kerangka Konsep}

A ntropologi ekonomi konsern kepada kajian masyarakat dan kebudayaan (Wilk, 1996). Konvergensi dari kajian kedua domain tersebut berpusat kepada fenomena pasar tradisional. Douglas $(1979)^{4}$ memandang bahwa pasar tradisi onal pada masyarakat kesukuan (tribal societies) merupakan pranata yang dibangun atas empat variabel yaitu pekerjaan yang produktif (productive works), jangkauan kerjasama antar pelaku ekonomi (range of collaboration), komoditas atau produk (product) dan rentang penyebaran komoditas (range of distribution) (1979: 89). Dengan demikian, pasar pada dasarnya terbangun dari suatu jejaring distribusi barang yang akan sangat berpengaruh kepada ketersediaan komoditi di tengah masyarakat lokal. Dalam konteks ini, aktor yang terlibat dalam pasar adalah (1) anggota masyarakat lokal, dimana mereka mengembangkan kolaborasi dalam tahap produksi, (2) pedagang/distributor, dimana mereka akan menyalurkan komoditas kepada sentra-sentra pemasaran/pasar, (3) penyelia jalur transportasi, dimana mereka akan membawa komoditas dan mengisi rentang jalur dari penyeberan komoditas.

Secara klasik, menurut Geertz (1992) tradisi kajian pasar tradisional dalam antropologi ditempatkan dalam studi tentang pasar yang beroperasi dikalangan masyara kat petani (peasant market). Dua pendekatan yang dipergunakan yaitu bazaar economy atau disebut juga "penny capitalism" dan pendekatan kelembagaan dimana pasar dianggap terbelenggu (embedded) di dalam konteks sosial budaya (Geertz, 1992: 225). Pendekatan yang pertama lebih mengarah kepada pemahaman pasar sebagai mana yang dirumuskan dalam pemikiran aliran ekonomi neo klasik, atau kaum formalist. Sementara pendekatan kedua lebih menunjukkan pasar dipahami sebagai bagian dari faktor-faktor sosial budaya, atau pandangan substantivis.

Dalam konteks masyarakat industri, pasar adalah salah satu pranata ekonomi dan gaya hidup yang membawa suatu

${ }^{4}$ Mary Douglas 1979. "Rafia Cloth Distribution in the Lele Economy", dalam George Dalton (ed) Tribal and Peasant economies: reading in economic anthropologies. Texas: University of Texas Press) masyarakat menjalankan transformasi sosial, budaya dan politik, dan merupakan bagian dari proses sosial (Polanyi, 1957, 1998; Evers 1997). Pada pengertian ini, pasar biasanya mengembangkan sendiri sistem internal (self-regulating) melalui berbagai aturan dan norma yang diberlakukan dalam konteks masyarakat lokal. Berdasarkan pemahaman ini, pasar, baik secara tradisional atau modern, memiliki gambaran pola ekonomi dan pola perubahan sosial. Berkait dengan pemahaman ini, pasar dapat menjadi indikator penting untuk melihat perubahanperubahan dalam sistem ekonomi suatu masyarakat yang bergerak dari ekonomi subsistensi kearah pola ekonomi pasar (Evers dan Schrader, 1994). Gambaran pasar hanya sebagai tempat bagi pemenuhan kebutuhan hidup dan berlangsungnya transaksi tidak selamanya dipahami apa adanya. Secara instrumen talis, pasar dapat menjadi tolok ukur tingkat perkembangan ekonomi suatu masyarakat, dengan melihat kepada produk dan tingkat akitivtas ekonomi dalam pasar.

Secara fisik, pasar (marketplace) adalah suatu tempat dimana pembeli dan penjual bertemu untuk menuntaskan transaksi-transaksi (Barnouw 1979). Keberadaan pedagang dan pembeli di pasar memberikan dasar bagi berlangsung nya hubungan ekonomi diantara mereka. Hubungan tersebut berlangsung dalam suatu transaksi. Hubungan transaksi ini dapat bersifat khusus atau umum. Transaksi khusus adalah bentuk transaksi yang diisi oleh muatan kekerabatan, pertemanan dan kebutuhan tertentu. Transaksi ini dicontoh kan seperti pedagang dan pembeli yang memiliki hubungan sosial menurut kekerabatan. Transaksi umum, adalah bentuk transaksi yang diisi oleh dasar kebutuhan dan tujuan ekonomi.

Secara instrumentalis, pasar dapat menjadi tolok ukur tingkat perkembangan ekonomi suatu masyarakat yang heterogen, dengan melihat kepada produk dan tingkat aktivitas ekonomi dalam pasar. Contoh konkrit, pasar tradisional tidak selamanya memperdagangkan kebutuhan subsistensi, seperti kebutuhan pokok (beras, sagu atau kentang), sayur-sayuran, dan sebagainya, tetapi pasar tradisional juga telah menjual kebutuhan lain yang konsumtif sifatnya, seperti menjual barang eletronik, pakaian 
dan alat-alat rumah tangga yang modern. Pasar juga menjadi orientasi bagai masyarakat untuk menjual hasil pertanian dan membeli kebutuhan hidup yang tidak lagi berasal dari produk lokal. Berdasarkan indikator tersebut, maka pasar tidak lagi semata sebagai gambaran ekonomi subsisten, tetapi sudah menjadi gambaran ekonomi konsumtif.

Berdasarkan keberadaan peda gang, pembeli dan dasar-dasar hubungan sosial yang berlangsung,maka pasar tradisional dapat diartikan sebagai suatu tempat dan gambaran keadaan hubunganhubungan (a place of affairs and state of affairs) (Barnouw 1979). Dalam konteks ini Hefner (1998:3) berpendapat bahwa proses yang berlangsung dalam pasar berkaitan dengan makna budaya dan seperangkat aktivitas manusia (human organization). Di pasar, para pedagang dan pembeli bertemu dalam dalam wadah tertentu, dan diantara mereka memiliki beberapa ciri hubungan sosial yang memperkuat pertemuan diantara mereka, misalnya kekerabatan, pertemanan atau hirarki. Perspektif yang dipakai untuk melihat pasar yang berlangsung dalam masyarakat adalah pranata ekonomi terikat atau terbelenggu (embedded) dalam sistem sosial (Polanyi 1944, Granovetter 1985, Plattner 1989). Artinya, mekanisme, perilaku, moral dan norma sosial adalah realitas yang sesungguhnya yang berlangsung dalam suatu pasar (lihat juga Szanton "Contigent Morality" 1998: 251).

Dengan melihat kepada pokokpokok pemahaman diatas tadi, maka pasar dipahami, secara teoritis dan empiris, sebagai elemen yang sangat penting untuk melihat bagaimana suatu budaya terimplementasi didalamnya dan direspon dalam dinamika ekonomi dan aktivitas sosial. Dengan demikian, pasar (market place) dipandang sebagai suatu tempat berlangsungnya aspek ekonomi dan sosial secara bersamaan.

5 Dalam kacamata ilmu ekonomi, pasar dianalisis hanya dari aspek ekonomi, seperti lokasi atau wilayah tempat bertemu antara pedagang dan pembeli, harga, komoditi, jasa, biaya transportasi, keuntungan, supply and demand, self-regulating mechanism, faktorfaktor produksi (tanah, uang, dan tenaga kerja) $\mathrm{dsb}$.

\section{$\mathrm{P}$}

D. Metode Penelitian

\section{Pendekatan Penelitian} enelitian ini menggunakan pendeka tan naturalistik. Metode penelitian kualitatif menjadi karakter utama riset yang akan dijalankan ini. Berbagai kasus dan fenomena empirik akan difokuskan dengan memanfaatkan kekuatan metode etnografi. Kekuatan metode ini adalah perilaku/tindakan sosial dan ungkapan kognitif pelaku dipelajari dalam konteks keseharian, dan bukan atas dasar kondisi yang diciptakan oleh peneliti; data dikumpulkan dari sejumlah sumber, baik secara verbal maupun tertulis/dokumen dan mengandalkan cara pengamatan terlibat dan/atau percakapan yang relative informal; fokus riset kepada sejumlah kasus yang umumnya berskala kecil agar dapat dilakukan studi yang mendalam; analisis data menggunakan interpretasi makna, fungsi dan segala konsekuensi yang ditimbulkan dari beragam tindakan manusia dan praktek kelembagaan dalam masyarakat (Hammersley dan Atkinson, 2007: 3). Substansi riset ini adalah ingin membangun suatu pengertian (understand ding) tentang fenomena budaya pasar yang bersifat tidak terlalu empiris (intangible). Selain itu, sifat fenomena yang dikaji tidak akan diperlakukan sebagai suatu bentuk kausalitas yang kaku dan diskrit, serta tidak untuk membangun kerangka hubungan, korelasi atau pengaruh antar variable riset. Untuk itu karakter riset kualitatif menjadi pilihan utama pelaksanaan riset ini.

\section{Lokasi}

enelitian dilaksanakan di kabupa ten yang dipilih secara purposif yaitu Kabupaten Tanah Datar yang berjarak sekitar $110 \mathrm{~km}$ dari kota Padang. Alasan pengambilan daerah ini sebagai lokasi penelitian adalah pasar tradisional, atau pasa nagari, masih berlangsung dan telah menjadi suatu gambaran budaya pasar tradisional yang sudah ada semenjak berabad silam. Sejauh ini, di wilayah kabupaten ini terdapat 42 buah pasa nagari yang beroperasi di sejumlah nagari (desa) dari 75 buah nagari yang ada. Ke-42 pasar tersebut tersebar di 10 kecamatan (Effendi, 2005; 2009). Di setiap kecamatan, masingmasing pasar dibuka umumnya seminggu sekali dan beroperasi dalam siklus yang berpindah dari satu nagari ke nagari lain 
dalam rotasi mingguan. Sehingga, masingmasing pasa nagari saling terkait penyelenggaraannya satu sama lain.

Dasar eksistensi pasar tradisional yang relatif masih bertahan dan beroperasi secara berpola menjadi alasan utama untuk mencari tahu suatu model penyelenggaraan pasar tradisional yang selaras dengan kondisi sosial dan budaya lokal. Sementara, kabupaten ini yang dikenal sebagai salah satu pusat kebudayan Minangkabau, juga tidak luput dari perubahan gaya hidup masyarakat akibat masuknya budaya pasar modern, keberadaan sejumlah pasar modern, sekelas mini market, yang sudah bersinggungan operasinya dengan pasar tradisional. Secara empirik, penelitian ini akan berupaya melihat bagaimana dinamika budaya pasar tradisional di tengah perkembangan pasar modern di tingkat lokal.

\section{Populasi dan Sampel}

Dopulasi penelitian adalah para pelaku pasar tradisional; antara lain pedagang, pembeli, penyedia jasa, pengurus pasar; yang inheren terlibat da lam aktivitas pasa nagari dan masyarakat nagari tempat dimana pasar tradisional berlangsung. Sampel penelitian akan dipelakukan terutama sebagai informan penelitian. Informan penelitian akan dibagi ke dalam dua kategori yaitu: pelaku yang terlibat langsung dengan pasar tradisional; dan masyarakat lokal dimana pasar tradisional berada/beroperasi.

Para informan adalah para pelaku pasar dan anggota masyarakat yang memanfaatkan pasar sebagai ruang ekonomi, sosial dan budaya, dan yang dianggap memiliki pengetahuan, pengala man dan persepsi yang terkait dengan budaya pasar. Mereka yang akan diteliti adalah pedagang tetap di dalam pasar, pemilik kedai, anggota pengurus pasar, anggota kepengurusan lembaga nagari, penyedia jasa fasilitas pasar (tukang payung/tenda, angkutan pasar), pembeli komoditas yang sering berbelanja di pasar, petani, toke.

\section{Teknik Penarikan Sampel/Informan}

ampel/informan akan didapatkan dengan teknik penarikan secara sengaja (purposive) dan kuota. Informan yang akan dipilih secara sengaja menurut penilaian dari peneliti, pengeta huan tentang masalah yang diteliti, pengetahuan peneliti dan keterlibatannya dengan populasi yang diteliti. Berdasarkan pengetahuan dan pengalaman peneliti, maka informan dipilih berdasarkan kriteriakriteria yang ditentukan sebelumnya. Kriteria-kriteria tersebut adalah: (1) Individu yang selalu terlibat dalam pasar tradisional (2) memiliki keterlibatan dan ketergantu ngan yang terus menerus dengan pasar dalam aspek sosial dan budaya (3) mengerti tentang persoalan pasar tradisional dalam masyarakat. (4) memiliki pengetahuan tentang norma, nilai dan etika yang berlangsung dalam aktivitas pasar tradisional.

Teknik penarikan informan lainnya adalah secara kuota atau sampel jatah (quota sampling).Sampel yang diambil akan dibagi dalam strata-strata menurut ciri-ciri yang berkaitan dengan permasalahan. Informan yang telah dikategori berdasarkan kriteria di atas, akan diambil secara proporsional secara sengaja.

\section{Teknik Pengumpulan Data}

$\mathrm{T}$ eknik pengumpulan data lapangan yang utama adalah pengamatan terlibat (participant observation) sepa ruh aktif, wawancara mendalam dan studi kasus. Pengamatan terlibat akan dilakukan dengan peran peneliti untuk terlibat di dalam aktivitas yang berlangsung dalam pasar tradisional dari waktu ke waktu. Peneliti akan berada langsung dalam suasana pasar sehingga dapat merasakan dan memahami konteks secara benar. Sejalan dengan teknik tersebut akan dilakukan perolehan data dari para informan dengan menggunakan wawancara mendalam. Wawancara ini akan menggunakan instrumen pedoman wawancara. Wawan cara mendalam ini akan dilakukan dengan dua bentuk yakni wawancara terbatas dan wawancara kolektif. Wawancara terbatas adalah bentuk tanya jawab antara peneliti dengan seorang informan (face-to-face). Sementara, wawancara kolektif akan dilakukan antara peneliti dengan beberapa informan yang relevan. Dalam pengalaman riset tentang pasar tradisional yang telah pernah dilakukan peneliti, bentuk wawancara kolektif adalah wawancara yang efektif dan lazim dihadapi. Argumennya, 
adalah keberadaan informan selalu terkait dengan jaringan sosial dan bisnis, sehingga diperlukan konfirmasi data dari satu informan ke informan lainnya.

Perolehan data berikut adalah dengan mengambil beberapa studi kasus. Studi kasus menurut Bogdan dan Biklen (1982) merupakan pengujian secara rinci terhadap satu latar atau satu orang subjek atau satu tempat penyimpanan dokumen atau satu peristiwa tertentu. Stake (1994: 236) menyatakan bahwa studi kasus merupakan suatu pilihan objek yang akan diteliti. Beberapa hal yang akan dilakukan dalam pemilihan kasus menurut petunjuk dari Stake (1994: 239-240) adalah (1) identifikasi ciri khas/keunikan situasi dari pasar tradisional, (2) mencari isu, yakni wacana/kondisi (circumstances) yang menjadi problematik di pasar tradisional; (3) penceritaan peristiwa yang menjadi representasi budaya pasar tradisional.

\section{Variabel Penelitian}

1 ariabel utama riset ini adalah:

1. Gaya hidup

2. Sistem pengetahuan

3. Nilai dan norma

4. Organisasi/Sistem penyelenggaraan pasar

5. Pelaku pasar

Dalam rencana proses penelitian, kelima variabel ini tidak akan dipertahankan secara kaku, artinya bersifat dinamis, atau berganti dengan variabel lain yang lebih relevan dan signifikan bila seandainya muncul atau ditemukan di lapangan. Tujuan utama proses penelitian dengan mencari dan membangun konstelasi variabel yang relevan ini adalah untuk suatu pemahaman (understanding) yang holistik tentang apa yang menjadi budaya dalam pasar tradisional.

Untuk memperjelas proses perla kuan variabel penelitian, digambarkan dalam skema kerangka pikir metodoligis, sebagai berikut:

Skema 1: Skema Pikir Riset

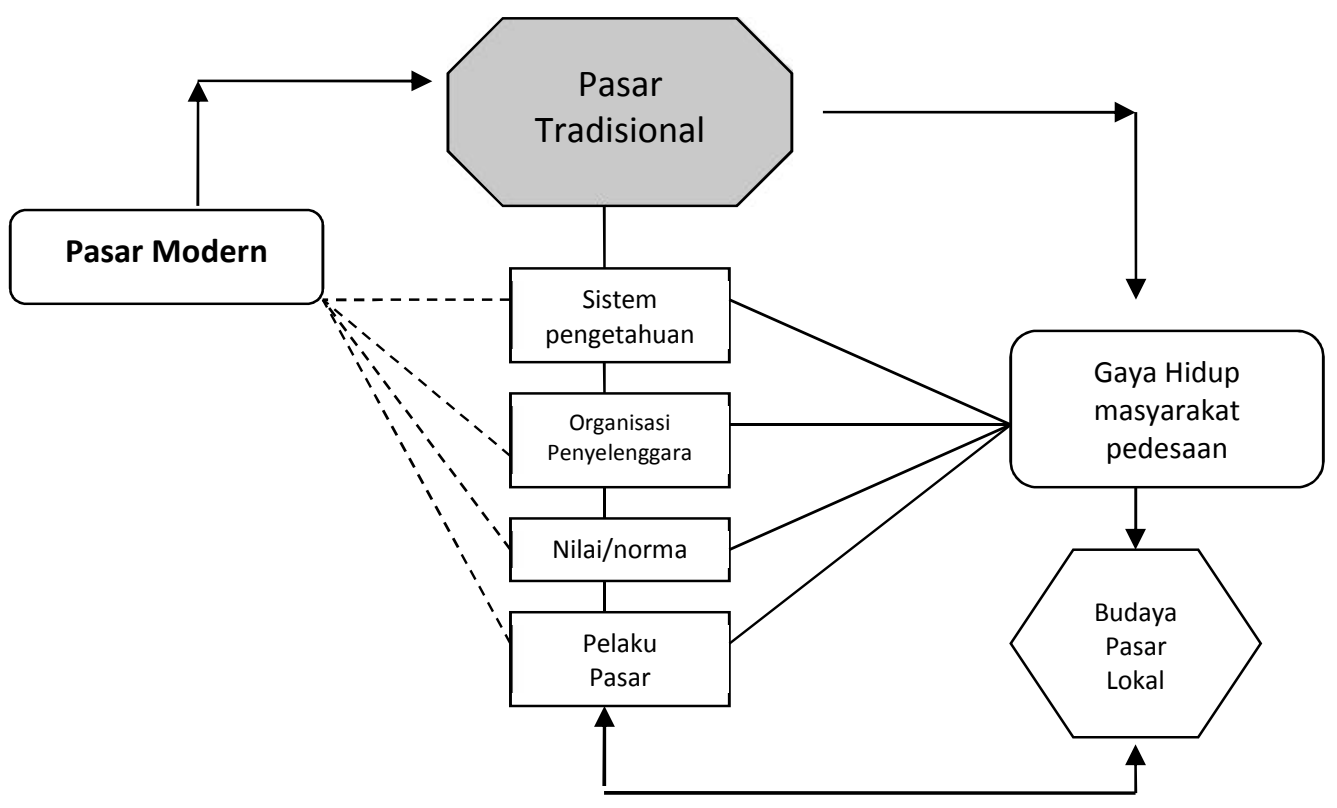

\section{Analisis Data}

nalisis data menggunakan pendeka tan kualitatif yakni dilaksanakan dalam tahapan proses/langkah- langkah penelitian. Analisis Data dianggap proses tanpa henti. Data yang diperoleh akan diorganisasikan berdasarkan kategori:

- Koding

- Indeks

- Sorting fisik data 
Upaya mengorganisasi data terse but termasuk kedalam langkah analisis dari manajemen data (lihat Huberman dan Miles, 1994). Dalam manajemen data ini akan di lakukan langkah:

a. Penentuan aksesibilitas dan kualitas data (relevansi data)

b. Pendokumentasian data yang diperoleh dari langkah sebelumnya.

c. Pemaknaan melalui konstruksi data yang telah dikomentasikan tersebut.

Data direkonstruksi berdasarkan kepada kerangka pemikiran yang telah dibangun pada rencana penelitian. Data kemudian akan dielaborasi menurut konsep utama/variable penelitian.

Data yang telah direkonstruksi akan diinterpretasi menurut pemahaman teoritis dan konseptual tentang fenomena yang diteliti.

Secara umum analisis data penelitian ini menganut model interaktif seperti yang dianjurkan oleh Huberman dan Miles (1994), yaitu

1. Pengumpulan data

2. Pereduksian data

3. Display data

4. Konklusi: terdiri dari penggambaran dan verifikasi.

\section{E. TEMUAN}

1. Konteks Kabupaten Tanah Data

Lokasi:

\section{Kabupaten Tanah Datar}

$\mathrm{B}$ (14 18 telah ada kerajaan Minangkabau yang berpusat di Luhak nan Tuo, sekarang termasuk wilayah Kabupaten Tanah Datar, dan wilayahnya meliputi kawasan yang terletak antara kerajaan Palembang dan Sungai Siak di sebelah Timur dan antara kerajaan Mandjuto dan Sungai Singkel di sebelah Barat (Manggis Dt. Radjo Penghulu, 1971: 24). Wilayah ini dikenal sebagai bagian dari keseluruhan wilayah budaya Minangkabau, yang disebut Alam Minangkabau. Alam Minangkabau ini digambarkan secara politik struktural dalam manifestasi sistem kerajaan. Ada komponen kerajaan yang dikenal yakni Kerajaan Alam, Kerajaan Ibadat dan Kerajaan Adat, sehingga di Minangkabau diakui ada Raja Alam yang berlokasi di Pagaruyung, Raja Ibadat di Lintau dan Raja Adat di Saruaso. Ketiga Raja atau sistem kerajaan ini juga menyimbolkan keberadaan pranata politik, agama dan adat dalam realitas masyarakat Minangkabau sejak dulu.

Kerajaaan Pagaruyung telah berada dalam konteks perkembangan peralihan dari masa kerajaan Hindu ke era Islam. Hal ini memberi kekuatan pemahaman bahwa kebudayan Minangkabau bergerak dari masa pengaruh Hindu sampai ke pengaruh agama Islam. Bukti-bukti berkembangnya kerajaan Minangkabau dewasa ini dapat dilihat pada prasasti-prasasti yaitu (Man soer, 1970):

a. Prasasti Kuburajo (1349) yakni pra sasti kuburan raja yang menceritakan antara lain tentang kepercayaan kematian tentang raja.

b. Prasasti Pagaruyung (1357) yakni menceritakan antara lain kebesaran Adityawarman melanjutkan pemerintahan raja-raja di Sriwijaya/ Jambi.

c. Prasasti Suruaso I (1357) yakin menceritakan antara lain pentasbihan Adityawarman sebagai Bhairawa, mahadewa Budha Trantayana.

d. Prasasti Bandar Bapahat yakni menggambarkan terdapatnya realitas kenekaragaman masyarakat pada masa kerajaan Pagaruyung, melalui pengenalan beberapa aksara seperti sumaera Kuno, Granta dan Sanskerta.

e. Prasasti suruaso II yakni menceritakan antara lain tentang putra mahkota kerajaan Pagaruyung.

Semenjak abad ke 15, ditengah berkembangnya pengaruh agama Budha /Bhairawa kerajaan Pararuyung juga mendapat pengaruhnya, selain pengaruh Islam dalam wilayah kerajaan juga telah ada. Dalam catatan sejarah dikatakan ada Sultan Alif yang hidup pada abad ke 16 yang menandai besarnya pengaruh agama Islam dalam wilayah Kerajaan Pagaruyung (Mansoer, dkk. 1970: 63). Pada masa pengaruh Islam dan Budha dalam Alam Minangkabau dikenal dengan sebutan Raja nan Tigo Selo. Ketiga raja tersebut adalah:

1. Raja adat yang berkedudukan di Buo

2. Raja ibadat yang berkedudukan di Sumpur Kudus

3. Raja alam di Pagaruyung.

Ketiga raja tersebut memiliki empat orang pendamping yang dikenal dengan sebutan Basa ampek Balai. Mereka adalah;

1. Datuk Bandaharo di Sugai Tarab. 
2. Tuan Khadi di Padang Ganting.

3. Tuan Indomo di Suruaso.

4. Tuan Machudum di Sumanik.

Dalam sejarah perkembangannya, wilayah Luhak nan tuo menjadi saksi bagi perkembangan dan dinamika kerajaan Pagaruyung yang dikatakan memiliki daerah-daerah kekuasaan yang menyebar jauh sampai ke wilayah Jambi dan Riau, seperti Siak, Indragiri, Jambi, Batanghari, Sungai Pagu, Pasaman dan Rao (Mansoer 1970).

Selain dinamika kewilayahan, Luhak nan Tuo telah mengalami perkembangan budaya dan agama, terutama di bawah pengaruh agama Islam. Dalam perkem bangan Minangkabau, pengaruh agama Islam semakin hari semakin menggantikan kedudukan pengaruh agama Budha dan Hindu dalam wilayah kerajaan Pagaruyung. Pengaruh ini terutama setelah terjadi pembaharuan agama Islam di Minangkabau yang dibawa oleh Haji Miskin, Haji Piobang dan Haji Sumanik. Pengaruh agama Islam yang kuat dalam mengubah paradigma social, politik dan budaya ini, kemudian menjadi momentum bagi proses keruntuhan Kerajaan Pagaruyung.

\section{Pasar Nagari di Tanah Datar}

$\mathrm{B}$ erdasarkan temuan dari kondisi dan unsur empiris dari pasar-pasar nagari di Tanah Datar, elemen-elemen yang dapat di angkat dari keberadaan pasar tradisional adalah sebagai berikut:

1. Terminologi.

2. Deskripsi fisik dan kategorisasi pasar.

3. Pelaku.

4. Pola operasional.

5. Jaringan sosial dan perdagangan.

6. Ekonomi rumah tangga.

7. Perkembangan.

(1) Pasar dalam setiap masyarakat dikenali dan diistilahkan berbeda-beda sesuai dengan sistem pengetahuan masya rakat yang bersangkutan. Orang Jawa menyebut dengan peken, orang Minang kabau menyebutnya dengan pasar, pasa atau balai, dan sebagainya. Sementara di beberapa daerah lain di Indonesia seperti Maluku dan Manado, disebut dengan istilah umum pasar. Terminologi tentang pasar dipakai untuk lebih jauh memahami tingkat kognisi masyarakat tentang suatu representasi pasar dan dinamika sosial yang berlangsung.

(2) Deskripsi fisik dan kategorisasi pasar pada setiap masyarakat berbeda, satu sama lainnya. Pasar tradisional biasanya mengacu kepada tempat atau lokasi tertentu, misalnya di Sumatera Barat, pasar berada diatas tanah ulayat kaum atau nagari, di Jambi pasar berada di tanah lapang atau tempat-tempat terbuka lainnya. Selain itu, pasar tradisional memiliki ciri-ciri fisik seperti terdapat los, tenda/payung, bangunan tidak permanen dan cenderung lokasinya berpindah-pindah. Dari sisi suasana, pasar bersifat terbuka, hiruk pikuk, tidak teratur dan beraneka ragam.Budaya transaksi pasar adalah tawar menawar (bargaining).Karenanya, pasar tradisional tidak semata diasumsikan sebagai tempat berdagang, tetapi juga terutama sebagai arena sosial dimana banyak individu membangun hubungan-hubungan sosial. Barnouw menyatakan bahwa pasar, dalam konteks masyarakat pedesaan,lebih meng gambarkan suatu state of affairs(1979).

(3) Hefner (1998: 2) berpendapat bahwa apabila ingin memahami kapitalisme yang berlangsung dalam pasar, perlu dianalisis secara kultural dan sosiologis tentang realitas para pelaku pasar dan tindakan-tindakan mereka. Di dalam pasar tradisional, biasanya individu yang terlibat dalam ikatan ekonomi berada dalam konteks mekanisme sosial masyarakat setempat. Pasar tradisional menampung para pelaku ekonomi dengan pola sosialnya yang majemuk. Untuk memahami format sosial tersebut, konsekuensinya berbagai posisi sosial dari aktor yang terlibat di dalam pasar perlu dicermati.Pada umumnya dalam pasar tradisional akan terdapat beberapa jenis pelaku pasar seperti:

a. Petani dan masyarakat desa

b. Makelar atau toke

c. Pedagang antar pasar (pedagang keliling)

d. Pedagang kios/warung.

e. Penyedia jasa.

f. Pengatur transportasi lokal

g. Aparat keamanan

h. Pengusaha lokal kelas menengah dan kecil

i. Pengelola pasar

j. Pengurus pasar

(4) Pelaksanaan aktivitas pasar tradisional biasanya berdasarkan kepada 
jadwal hari dan tempat. Pasar umumnya berlangsung seminggu sekali dan pada tempat yang berbeda-beda (pasar berpindah-pindah). Pola operasional terse but dikenal dengan istilah rotating market, atau periodical market, atau weekly market atau market circulation(Effendi, 1999).Dasar pemikiran dari belangsungnya operasional pasar yang berbeda hari dan tempat adalah karena tindakan para aktor pasar dibatasi oleh unsur-unsur identitas, kepentingan dan kapasitas mereka untuk terlibat dalam pasar (Friedland dan Robertson, 1990).Unsurunsur tersebut akhirnya mempengaruhi batas, bentuk dan performance dari pasar.

(5) Jaringan sosial dan perda gangan dalam pasar tradisional berlangsung dengan kuat. Dasar pengoperasian pasar tradisional yang khas telah mendukung jaringan tersebut. Pola jaringan yang terbentuk diartikulasikan dalam beberapa bentuk seperti kerja sama, pertemanan, perjanjian dagang, atau amanat (kasus Sumatera Barat, Mulyadi 2005). Jaringan sosial sering juga dibangun atas dasar perasaan senasib sepenang gungan. Jaringan pemasaran berlangsung antara pelaku pasar di pasar lokal, dengan pelaku pasar di kota, dan dengan distributor di pasar lokal dan kota. Fungsi jaringan sosial dan perdagangan dalam konteks pasar tradisional adalah untuk penyediaan yang berkelanjutan akan barang dagangan, mengurangi kompetisi dagang dan meme lihara keuntungan usaha.

(6) Keberadaan pasar tradisional akan mempengaruhi orientasi ekonomi rumah tangga dari masyarakat yang berada di dan sekitar pasar tradisional. Pengaruh tersebut antara lain: menjadikan produk pertanian sebagai komoditas dan bukan subsistensi, praktek tenaga kerja upahan, peran wanita dan laki-laki sebagai pelaku pasar, komersialisasi tindakan dan strategi mempertahankan hidup berdasarkan ke pada prinsip pasar.

(7) Eksistensi pasar akan mempengaruhi perkembangan proses sosial dari masyarakat setempat. Proses sosial ini dapat berupa integrasi, yakni menerima pasar sebagai bagian dari aktivitas sosial dengan konsekuensi bahwa kebiasaan dan tradisi beradaptasi dalam pasar, dan berupa resistensi yakni menolak pasar atau menolak mengadaptasikan pasar dalam kebiasaan dan tradisi sosial masyarakat setempat. Operasional pasar tradisional dalam jangka waktu yang lama menandakan telah terjadinya integrasi pasar dalam sistem sosial

Secara fungsional, keberadaan pasar tradisional menjalankan sejumlah fungsi utama yaitu:

1. Tempat atau arena dimana pembeli (permintaan/demand) dan penjual (penawaran/supply) bertemu dan terli bat untuk tujuan tukar menukar secara langsung. Dalam fungsi ini diperlukan wilayah/ruang, pelaku, supply-demand, transaksi, harga.

2. Tempat berlangsungnya mekanisme komersialisasi dalam konteks masya rakat lokal. Mekanisme pasar bersifat swa kelola(self-regulating) dan inter vensi (penetratedmechanism).

3. Tempat saluran keluar (outlet) dari karakter sosial budaya yang berlaku di dalam masyarakat secara keseluruhan.

Pasar tradisional, khususnya pasar di pedesaan, konsekuensinya, dapat menjadi analisis dasar untuk mengamati kondisi sosial budaya dari suatu masyarakat lokal. Ada tiga indikator dari posisi pasar yang dapat dipakai untuk pengamatan tersebut:

(1) pasar berperan krusial dalam ritmus sosial dalam ekonomi, baik dalam kehidupan publik dan domestik di masyarakat lokal.

(2) Pasar sebagai faktor yang dapat merubah perilaku sosial suatu masyarakat. Pada poin ini, maka pasar dapat dipakai untuk mendeteksi dan meninjau lebih dalam terjadinya perubahan gaya hidup masyarakat di dalam dan di sekitar pasar.

(3) Pasar masyarakat lokal merupakan mata rantai dari pasar-pasar di tingkat nasional, regional dan bahkan global melalui akses arus komoditi/barang dan jasa, serta jaringan pedagang.

\section{Gaya Hidup: Masyarakat Nagari di Tanah Datar}

$\mathrm{M}$ enurut Johnson (1995: 159)), gaya hidup (lifestyle) adalah suatu pola hidup yang mendasari kepada penggunaan berbagai barang dan jasa dalam berbagai wujud seperti selera dalam music, seni, film dan bebeapa produk budaya, dan wujud pilihan dalam 
kesenangan hidup. Lebih jauh Johnson menyatakan bahwa gaya hidup seringkali dipelajari dalam kaitannya dengan suatu karakterstik sosial seperti kelas sosial. Kajian gaya hidup juga memperdalam studi penyimpangan dan gaya hidup alternative yang terjadi pada kehidupan di masyarakat desa, kota dan pinggiran kota, dan efek pola gaya hidup pada kesehatan emosional dan fisik ( Johnson 1995: 159).

Masyarakat pedesaan di Sumatera Barat, khususnya pada masyarakat nagari, telah mengalami perubahan gaya hidup. Pola kehidupan dasar masyarakat nagari adalah petani, sawah, ladang, dan perkebunan. Kehidupan masyarakat petani memiliki dua klasifikasi utama yaitu rumah tangga dalam komunitas dan lahan usaha, persawahan. Perladangan atau hutan. Dalam lingkungan komunitas, rumah tangga petani menganut ikatan kekeluargaan dan keeratan sosial berstandar norma sosial yang ketat (gemeinschaft). Tipe keluarga berpola keluarga luas dalam suatu lingkup bertetangga dalam suatu pekarangan (compound).

Petani merupakan suatu kelas sosial yang juga mendapat tantangan untuk mengalami perubahan gaya hidup.
Berdasarkan pendapat dua informan di pasar Rao-Rao, Tanah Datar, dinayatakan bahwa kehidupan masyarakat di nagari Rao-rao telah berubah. Perubahan yang tampak nyata adalah kepemlikian benda yang lebih konsumtif, yaitu hp dan sepeda motor. Perubahan yang nyata akibat kepemilikan tersebut adalah anggota masyarakat harus memenuhi kebutuhan hidup untuk biaya pulsa dan bensin untuk motor.

Seorang informan berpendapat bahwa biaya pulsa anggota masyarakat minimal Rp.5.000/hari, dan bensin sekitar 2 liter/perhari. Tuntutan perubahan gaya hidup ini dianggap tidak seimbang dengan pemasukan dari pertanian. Sekitar 15 tahun lalu, masyarkat harus pergi ke ibu kota kabupaten di Batusangkar untuk membeli bensin untuk kendaran, namun dewasa ini di nagari tetangga, yaitu nagari Sungai Tarab, telah berdiri sebuah stasiun pompa bensin. Stasiun ini berada di perbatasan antara nagari Sungai Tarab dan batas kota Batusangkar. Semakin mudah masyarakat untuk mencari bensin. $\mathrm{Di}$ ibu kota Batusangkar sekitar 15 tahun lalu hanya terdapat 1 buah stasiun BBM, dewasa ini di tahun 2014 sudah ada 3 buah.

\section{Foto: Sebuah Stasiun BBM di Nagari Limo Kaum yang baru berdiri sekitar 3 tahun lalu.}

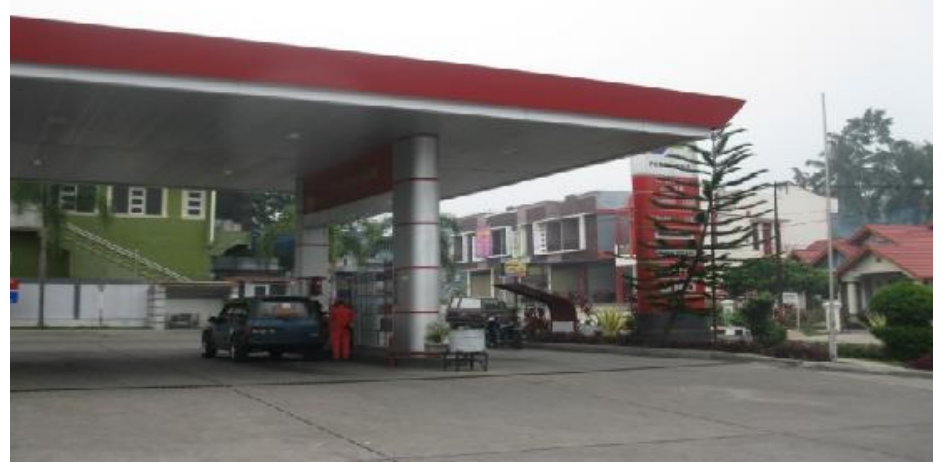


Untuk memenuhi kebutuhan pulas, dewasa ini di nagari-nagari telah banyak kios-kios pulsa yang menjajakan tawaran pulsa dari berbagai provider. Melalui sistem voucher pulsa berpola pra bayar (pre-paid), anggota masyarakat sudah dapat mengoperasikan telpon genggam (hp) kapan dan dimanapun. Antena telpon seluler atau disebut BTS telah menjangkau seluruh wilayah kota dan desa-desa (nagari).

\section{Foto: Kios Kelontong dan Voucher Pulsa di Nagari}

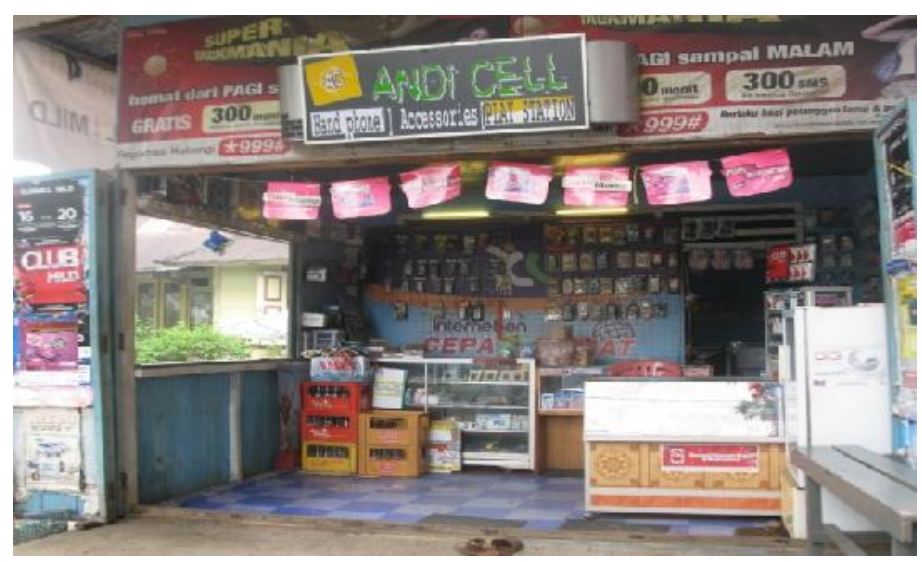

Kios kelontong pada masyarakat di nagarinagari pada masa lalu umumnya menjual makanan dan minuman, namun dewasa ini telah menjual komoditi utama voucher untuk telpon hp.

Dua fenomena temuan lapangan, yaitu stasiun BBM (pom bensin) dan kios voucher pulsa telah memberikan jalan masuk bagi pemahaman tentang perubahan gaya hidup masyarakat pedesaan di Tanah Datar. Kesenangan hidup dan selera perilaku telah ditunjukkan dengan memiliki kendaran bermotor, terutama sepeda motor dan telpon seluler.

Gaya hidup yang berubah ini, sebagian berpendapat tidak mencerminkan suatu kesenangan sejati. Karena kesulitan hidup dengan bertambahnya pemilikan barang dalam rumah tangga yang lebih bersifat konsumtif, justru melahirkan keluhan yang terus muncul sehari-hari. Keluhan tersebut adalah tidak seimbagnya hasil pertanian dengan pengeluaran kebutuhan hidup. Seorang informan menyatakan bahwa petani kelas bawah sekarang ini hidupnya makin susah. Hasil pertanian sawah dan ladang, telah bergeser kepada usaha tanaman tani berupa coklat. Sementara perkembangan pasar nagari tidak signifikan untuk menopang hasil pertanian.

Perubahan yang nyata dari pasar nagari adalah, semakin banyaknya produk- produk non pertanian di jual di dalam pasar. Sejumlah komoditi tersebut merupakan produk pabrik yang tidak dibuat oleh masyarakat lokal setempat, seperti barang pecah belah, container alat rumah tangga dari plastik, sapu dari plastik.

Sejumlah komoditas dan unsur pasar yang muncul baru di dalam lingkungan nagari adalah:

1. Alih fungsi lahan berupa komplek perumahan real estate, sperti Rizano real estate (di Nagari Cubadak), Arai Pinang dan Griya Limo Kaum

2. Kecantikan dan Kosmetik, misalnya Liza Salon

3. Hotel, seperti hotel Bougenville di Limo Kaum

4. Warung internet, sperti Nayla.net di Limo Kaum

5. Service Kendaraan Bermotor, seperti Pangeran Motor di Limo Kaum

6. Haji dan Umrah, seperti PT Hikmah Sakti Persada, di Batu Sangkar

Perubahan lingkungan pasar juga terjadi di sekitar pasar tradisional Sungari Tarab, sekitar 5 kimlometer dari ibukota Tanah Datar di Batusangkar. Pasar ini tergolong pasar tradisional, salah satu pertanda pasar tradisional adalah adanya los pasar, atau bangunan besar lepas tanpa dinding, hanya beratap. Di bawah atap ini biasanya tempat berdagang para pedagang kecil yang saling 
berdampingan. Sekitar 18-19 tahun lalu (1996-1997) pasar ini hanya terdiri dari beberapa kios kecil yang berjejer di bagian belakang los pasar, yang terletak persis di tengah lokasi pasar. Dewasa ini, di tahun 2014, lingkungan fisik ini telah banyak jauh berubah. Losa pasar terjepit diantara deretan kios permanen yang dibangun mengelilingi kios tersebut. Beberapa unsur perbuhan yang dapat diamati adalah:

1. Keberadaan deretan ruko yang persis berhadapan diseberang jalan dengan lokasi pasar. Deretan ruko tersebut berjumlah 9 petak (pintu).

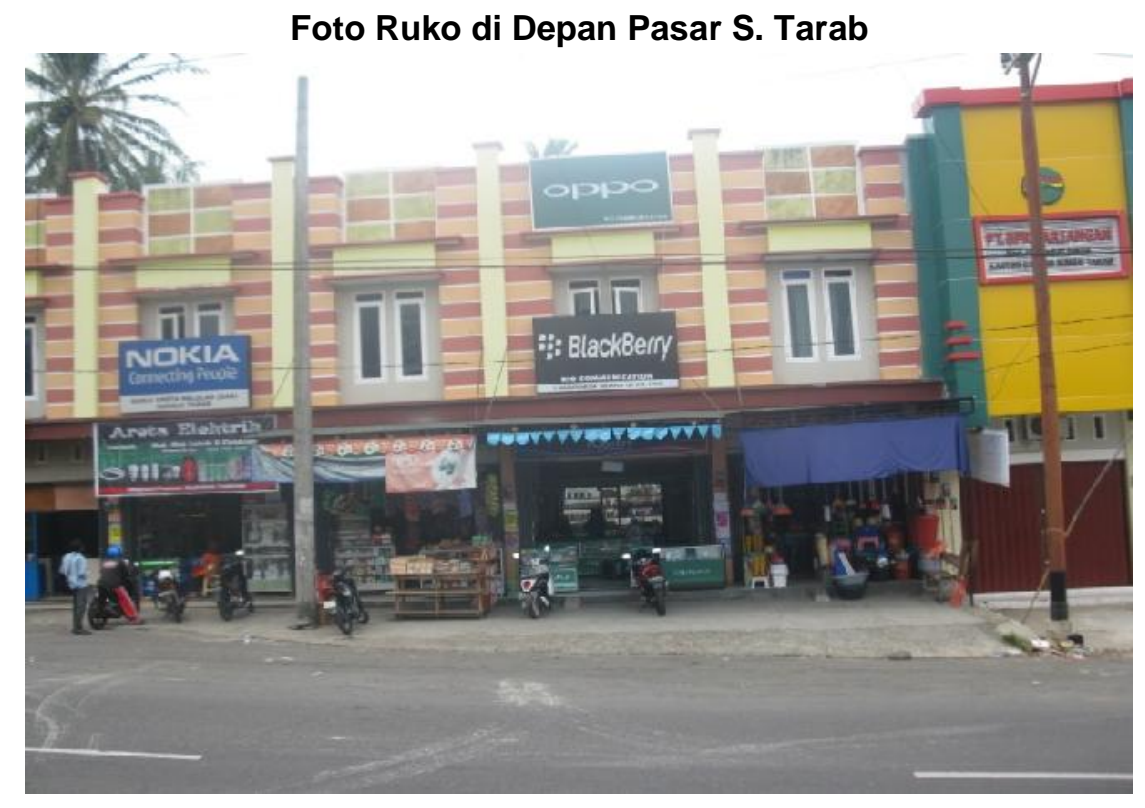

Komoditi yang dijual di kesembilan ruko tersebut adalah
a. Warnet "Areta"
b. Elektronik; Alat-alat listrik dan elektronik
c. Toko telpon seluler, branding "Oppo" dan "Nokia"
d. Toko P\&D
e. Alat-alat rumah tangga
f. Bank Perkreditan Rakyat, PT BPR Priangan
g. Photo Studio
h. Toko Baby shop
i. Toko Mas, "Bintang Andalas"

2. Antena tv kabel (Indovision) yang berada di rumah penduduk, dahulu kebanyakan hanya antenna parabola.

3. Pasar ini sudah memiliki bangunan kios yang beraneka ragam yang disebut LOSERBA (los seba guna) .

4. Ada layanan hiburan berupa organ tunggl "Penganten music program".

\section{F. KESIMPULAN}

erdasarkan hasil penelitian, data yang terungkap dari lapangan dapat disimpulkan bahwa:

1. Keberadaan toko-toko baru yang menjual berbagai kebutuhan hidup di luar kebutuhan standar seharihari telah tumbuh sangat jelas, mulai dari kebutuhan kosmetik, alat rumah tangga, perhiasan sampai dengan komunikasi canggih. Tawa ran kebutuhan konsumerisme dan cenderung berbasis modern telah tampak di dalam lingkungan masyarakat nagari.

2. Pasar tradisional sebagai lembaga ekonomi lokal telah turut andil dalam penyediaan kebutuhan yang konsumtif dan modern, sehingga 
berkontribusi dalam menciptakan gaya hidup baru di nagari/pedesaan.

3. Pasar tradisional/pasar nagari telah menjadi tempat belangsungnya transaksi produk ekonomi global, disamping produk ekonomi lokal yang cenderung semakin terping girkan.

4. Dengan demikian, budaya pasar tradisional dewasa ini telah me ngalami percampuran dengan budaya pasar modern melalui indikator keberadaan produk-produk yang bersifat konsumtif dan modern, dan gaya hidup masyarakat di sekitar pasar yang cenderung untuk aktivitas kesenangan dan gaya hidup alternative, selain kehidupan pertanian.

\section{Daftar Pustaka}

Barnow, Victor, 1979. Anthropology.lllinois: The Dorsey Press.

Bogdan, Robert C. dan Sari Knop Biklen. 1982. Qualitative Research for Education: An Introduction to Theory and Methods. Boston: Allyn and Bacon, Inc.

Ditjen NBSF. 2005. Pasar Tradisional dan Hypermarket: Apakah Bisa Saling Bersinergi?. Booklet Program Budaya Pasar Tradisional

Dalton, George. 1979. Peasant Markets. Dalam Journal of Peasant Studies. Hal. 240-243

Douglas, Mary. 1979. "Rafia Cloth Distribution in the Lele Economy", dalam George Dalton (ed) Tribal and Peasant economies: reading in economic anthropologies. Texas: University of Texas Press

Effendi, Nursyirwan.1999. Minangkabau Rural Markets: Their System, Roles and Functions in the Market Community of West Sumatra, Indonesia.Disertasi pada Faculty of Sociology, University of Bielefeld, Germany

Effendi, Nursyirwan. 2005. Trade and Traders in West Sumatra. Muenster: LIT Verlag

Efendi, Nursyirwan dan Yunarti. 2009. Analisis Budaya Pasar Tradisional dalam Mendukung Ketahanan Pangan Masyarakat Pedesaan: Kasus di Propinsi Sumatera Barat. Laporan Penelitian Hibah strategis Nasional - DIKTI - LP Universitas Andalas

Evers, Hans-Dieter dan Heiko Schrader (editor). 1994. The Moral Economy of Trade: Ethnicity and Developing Markets. London: Routledge

Evers, Hans-Dieter. 1997. "Globalisasi dan Kebudayaan Ekonomi Pasar", dalam Prisma. Jakarta: LP3ES. No. 5.

Friedland, Roger dan A.F. Robertson (ed). 1990. Beyond the Marketplace: Rethinking Economy and Society. New York: Aldine de Gruyter.

Geertz, Clifford. 1963. Peddlers and Princes: Social Change and Economic Modernization in Two Indonesian Towns. Chicago: The University of Chicago Press

Geertz, Clifford.1992. "The Bazaar Economy: Information and Search". Dalam Mark Granovetter dan Richard Swedberg. (ed). The Sociology of Economic Life. San Fransisco: Westview Press

Granovetter, Mark. 1985. „Economic Action and Social Structure: The Problem of Embeddedness". Dalam: AJS. Vol. 91. No. 3. Halaman 481-510

Hammersley, Martyn dan Paul Atkonson. 2007. Ethnography: Principles in Practice. London: Routledge

Hefner, Robert W. (ed). 1998. Market Culture: Society and Morality in the New Asian Capitalism. Colorado: Westview Press

Huberman, A. Michael dan Metthew B. Miles. 1994. "Data Management and Analysis Methods". Dalam Norman K. Denzin dan Yvonna S. Lincoln. (ed). Handbook of Qualitative Research. London: Sage Publications

Johnson, Allan, G. 1995. The Blackwell Dictionary of Sociology. Cambridge: The Blackwell

Koentjaraningrat. 1996. Pengantar Antropologi.Jakarta: Rineka Cipta

Manggis, M.Rasjid, Dt Radjo Penghoeloe.1971. Minangkabau Sedjarah Ringkas dan Adatnya. Padang: Sridharma

Mansoer, M.D.Dkk. 1970. Sedjarah Minangkabau. Jakarta: Bhratara 
Mulyadi. 2005. Perdagangan Amanat: Kasus Pasar Aur Bukittinggi. Skripsi Sarjana S1, Jurusan Antropologi FISIP Universitas Andalas

Plattner, Stuart. 1989.Economic Anthropology. California: StanfordUniversity Press

Polanyi, Karl. (1944) 1957. The Great Transformation. Boston: Beacon

Polanyi, Karl, et.al. 1988. "Ekonomi sebagai Proses Sosial". Dalam Hans-Dieter Evers. Teori Masyarakat: Proses Peradaban dalam Sistem Dunia Modern. Jakarta: Yayasan Obor Indonesia

Stake, Robert E. 1994. "Case Studies". Dalam Norman K. Denzin dan Yvonna S. Lincoln. (ed). Handbook of Qualitative Research. London: Sage Publications

Szanton, David L.1998. "Contigent Moralities: Social and Economic Investment in a Philippine FishingTown". Dalam Robert W. Hefner (ed). Market Culture: Society and Morality in the New Asian Capitalism. Colorado: Westview Press

Wilk, Richard, R. 1996. Economies and Cultures. Oxford: Westview Press 